\title{
The Hypocrisy of the West
}

\begin{abstract}
One of the great gifts of Western civilization is the philosophical wisdom bequeathed by its great thinkers. At a time when torture and Guantanamo still exist, the West should revive its commitment to using reason to understand and improve the world.
\end{abstract}

One of the greatest joys of my life was studying Western philosophy, absorbing the wisdom of great Western thinkers from Socrates to Wittgenstein. The dedication of all those great thinkers, over thousands of years, to the power of logical reasoning, was truly inspiring. Hence, for me, the power of the West was always associated with this commitment to using reason to understand and improve the world.

Western logic was always irrefutable. Plain logic would create irrefutable statements. Hence if the premise was "all dogs are animals", the consequence of the claim "Fido is a dog" was the irrefutable statement that "Fido is an animal". A similar rigor applied to moral reasoning. Hence, if a human being called X said "Human beings should not torture other human beings", the irrefutable conclusion was that X was obliged to also say "I should not torture human beings". The rigor of this logic is absolute. No exceptions are possible. Anyone who made the first claim and denied the second claim would be justifiably accused of hypocrisy.

\section{In Theory, the West Condemns Hypocrisy-In Practice, It Indulges in it}

In theory, the West condemns hypocrisy. In practice, sadly, it indulges in hypocrisy massively. A few major contemporary examples will illustrate this. For several decades, after the US Congress passed legislation instructing the US State Department to publish annual reports on the human rights performance of all states in the world (except the US), the US State Department would painstakingly record the

Originally published in IAI, Dec 16, 2020 
cases of torture practiced in other countries. ${ }^{1}$ For example, the State Department condemned "near drowning" and "submersion of the head in water" as torture in reports on Sri Lanka and Tunisia. By the logic of moral reasoning, the US was declaring that it did not practice torture.

In 2001, after 9/11 happened, the US went on a global campaign against the radical Islamist terrorists that had attacked it. Under international law, this campaign was justified, especially since it was legitimized by a UN Security Council resolution. ${ }^{2}$ However, after the US captured some terrorist suspects, it took them to Guantanamo and tortured them. By so doing, the US was clearly declaring that it had shifted its moral stance from "Thou shalt not torture human beings" to "Thou shalt torture human beings". The US never said this verbally, but by the logic of moral reasoning, it had made this statement even more loudly with its actual behavior.

One of the greatest modern works of moral philosophy is the book "The Language of Morals" by the English philosopher, R.M. Hare (Note: as an aside, let me mention that he wrote parts of this book on toilet paper when he was a prisoner of war of the Japanese in Singapore in World War II). The opening line of this volume is very powerful. It says "If we were to ask of a person 'What are his moral principles?' the way in which we could be most sure of a true answer would be studying what he did." 3

\section{"Thou Shalt Torture Human Beings"?}

In short, since Western moral reasoning is brutally ironclad and allows no exceptions, when the US began torturing human beings, it was declaring "Thou shalt torture human beings". Since this was undoubtedly the moral position taken by the US, the logical consequence should have been for the US State Department to stop issuing annual reports "condemning" torture in other countries. Clearly, this would be hypocritical. Quite amazingly, the US State Department did not stop. Even more amazingly, the largest and most powerful "moral industry" in the world is in the US: No country can match the output of moral judgments that spew out from the editorial pages of the New York Times and Washington Post and from the reports of the greatest think tanks and universities in the world. This massive "moral industry" should have exploded in outrage at this blatant hypocrisy of the State Department Reports. None of this happened. The annual State Department reports continued to be published and reported and cited in, for example, the New York Times. If Socrates

\footnotetext{
${ }^{1}$ Under the Foreign Assistance Act of 1961. These annual country reports have been published since 1977.

${ }^{2}$ UN Security Council Security Council resolution 1373 (2001) [on threats to international peace and security caused by terrorist acts], 28 September 2001, S/RES/1373 (2001), available at: https:// www.refworld.org/docid/3c4e94552a.html

${ }^{3}$ Richard Mervyn Hare. The language of morals. No. 77. Oxford Paperbacks, 1991: 1.
} 
were alive today, he would have made the next logically irrefutable statement: the New York Times was abetting the hypocrisy of these reports.

The second largest "moral industry" in the world, outside the US, can be found in Europe. Most European governments have not hesitated to condemn countries like Russia and Iran when they received reports of "torture" in these countries. By the logic of moral reasoning that flows from the statement "thou shalt not torture", the same European governments should have immediately condemned the US for practicing torture. Amazingly, to this day, not one European government has done so. Neither have they been called to account by their "moral industry" over their failure to be logically consistent and condemn the US. Here too, we saw a massive dose of hypocrisy.

Even more importantly, all moral philosophers have emphasized that the best way to demonstrate one's fidelity to moral principle is not when it is convenient to do so, without any sacrifice involved. Hence, when European governments condemned, for example, the dictatorial rule of, say, Mugabe in Zimbabwe or Hugo Chavez in Venezuela, they could do so happily as they would not pay any political and economic price for taking these correct moral stances. Since no costs are involved, there is no real demonstration of moral commitment. This is why the non-condemnation of the US practice of torture is very significant. By failing to condemn when the costs of doing so were high (as there could have been retribution from the US), the European governments were showing their real moral stand by, as R.M. Hare says, what they did. Hence, when they did not condemn, they were essentially saying that their true moral position was "thou shalt torture human beings".

In 2021, we will be marking the twentieth anniversary of 9/11 and the subsequent moral distortions it unleashed in major Western societies. Since sufficient time has passed after the US exploded in anger when it was attacked, this may be a good time for all major Western governments, including those of the US and the European Union, to reflect deeply on their clear failure to abide by some of their most cherished moral principles. One point is clear. One of the heinous acts one could carry out on a human being is to practice torture. Indeed, before 9/11, there was a solid consensus among all the Western countries that torture was unjustified in all circumstances.

\section{End the Hypocrisy}

The world would be a better place if all Western governments would once again demonstrate, in words and deeds, their total adherence to the strong moral statement "Thou shalt not torture". Guantanamo should be shut down. All the European governments, which were silently complicit in this torture campaign by providing "rendition" centers, should make a clean break with these practices by declaring openly all that had been done so that the chapter on this painful episode in the history of the West can be closed. 
At the end of the day, one of the greatest strengths of Western civilization is the large oceans of philosophical wisdom bequeathed by the greatest Western thinkers. Fidelity to the great principles left behind by these great Western philosophers would help to repair the damage done to the standing and prestige of the West after its unholy flirtation with torture. This stain can and should be removed from the West.

Open Access This chapter is licensed under the terms of the Creative Commons AttributionNonCommercial-NoDerivatives 4.0 International License (http://creativecommons.org/licenses/bync-nd/4.0/), which permits any noncommercial use, sharing, distribution and reproduction in any medium or format, as long as you give appropriate credit to the original author(s) and the source, provide a link to the Creative Commons license and indicate if you modified the licensed material. You do not have permission under this license to share adapted material derived from this chapter or parts of it.

The images or other third party material in this chapter are included in the chapter's Creative Commons license, unless indicated otherwise in a credit line to the material. If material is not included in the chapter's Creative Commons license and your intended use is not permitted by statutory regulation or exceeds the permitted use, you will need to obtain permission directly from the copyright holder.

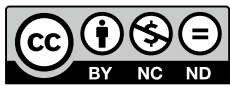

